University of Rhode Island

DigitalCommons@URI

2018

\title{
How the West Lost Russia: Explaining the Conservative Turn in Russian Foreign Policy
}

Nicolai N. Petro

University of Rhode Island, npetro@uri.edu

Follow this and additional works at: https://digitalcommons.uri.edu/psc_facpubs

The University of Rhode Island Faculty have made this article openly available.

Please let us know how Open Access to this research benefits you.

This is a pre-publication author manuscript of the final, published article.

Terms of Use

This article is made available under the terms and conditions applicable towards Open Access

Policy Articles, as set forth in our Terms of Use.

Citation/Publisher Attribution

Petro, Nicolai N. "How the West Lost Russia: Explaining the Conservative Turn in Russian Foreign Policy". Russian Politics 3.3: 305-332. https://doi.org/10.1163/2451-8921-00303001 Web.

Available at: https://doi.org/10.1163/2451-8921-00303001

This Article is brought to you for free and open access by the Political Science at DigitalCommons@URI. It has been accepted for inclusion in Political Science Faculty Publications by an authorized administrator of DigitalCommons@URI. For more information, please contact digitalcommons-group@uri.edu. 


\title{
How the West Lost Russia: \\ Explaining the Conservative Turn in Russian Foreign Policy
}

\author{
Nicolai N. Petro ${ }^{1}$ \\ (npetro@uri.edu)
}

To be published in Russian Politics, vol. 3, No.3 (Fall 2018)

A decade ago many Russian analysts concluded that the West's efforts to preserve its global superiority would be futile and the emergence of a polycentric world was inevitable. To benefit from this transition Russia should adopt a strategy that combined great power realism and "traditional" Russian values. This strategy, first elaborated in Vladimir Putin's Valdai Speech of 2013, is known as 'Civilizational Realism'.

This article describes the emergence of Russia's new sense of self-worth, how and why Russia gradually lost faith in the West as a potential partner, and how, through the internal adoption and external projection of conservative multicultural values, Russia hopes to forge a new, and more pluralistic, world order.

Key words: Russian foreign policy; Putin Plan; Vladislav Surkov; Boris Mezhuev; Sergei Karaganov; Russian Orthodox Church; Ukraine; NATO, post-Containment; Soft Power

\section{Russia's Post-Cold War Strategy -- the Putin Plan}

Reeling from the sudden collapse of the U.S.S.R., Boris Yeltsin's Russia had no coherent approach to foreign policy and no global strategy. Its foreign policy, like its domestic policy, was sharply divided between those who looked to the West for support and guidance in transforming Russia into a more European country, and those who hoped for a restoration of, if not quite the USSR, then at least Russia's status as a regional Great Power. The former view was exemplified by foreign minister Andrei Kozyrev, who seemed ever in search of the Russian national interest. The latter view was the hallmark of his immediate successor, Yevgeni Primakov.

The appointment of Vladimir Putin to succeed Yeltsin as president did not immediately resolve this conflict. Indeed, there is strong evidence suggesting that during his first term in office, Putin himself was ambivalent about which course to choose, and even considered the possibility of Russia eventually joining both the European Union and NATO. ${ }^{2}$

He eventually decided, however, that neither option would be possible unless Russia ended its humiliating economic dependency on the West. Russia's prosperity thus became a precondition for the restoration of the country's freedom to act independently in international politics.

\footnotetext{
${ }^{1}$ Nicolai N. Petro is professor of political science and currently holds the Silvia-Chandley Professor of Peace Studies and Nonviolence at the University of Rhode Island. An earlier version of this paper was presented at the Leader Development and Education for Sustained Peace Program for military leaders, Fort Carson, Colorado Springs, January 26-27, 2017.

2 “'Putin asked NATO Secretary General George Robertson at their first meeting, in February 2000, when Russia would be able to join the alliance.' Robertson was not prepared for the question". Cited by Michael Weiss, "When Donald Trump Was More Anti-NATO Than Vladimir Putin", The Daily Beast, 4 November, 2016, http://www.thedailybeast.com/when-donald-trump-was-more-anti-nato-than-vladimir-putin (accessed 10 November 2016).
} 
The key to restoring Russian greatness, as Putin saw it, lay in restoring the effectiveness of the state institutions that had so precipitously unraveled under Yeltsin. Some of the major reforms begun during Putin's first term include: the temporary appointment of governors, reforming or moving unconstitutional regional laws, dramatically increasing funding for the judiciary, introducing new legal codes, strengthening of political parties, and reasserting state control over strategic sectors of the economy. ${ }^{3}$ It is a sign of the public's growing confidence in the judicial system, that the number of persons turning to courts for redress of civil grievances has gone from one million in 1998 , to six million in 2004 , to ten million in $2012,{ }^{4}$ to more than 17 million in $2016 .^{5}$

By strengthening of state institutions, harmonizing local and federal legislation, and paying off foreign debt early, the 'Putin Plan', as it was later dubbed, sought to reverse the economic ravages of the Yeltsin years which, as economist Joseph Stiglitz notes, had reduced Russia's industrial production almost $60 \%$. By comparison, Stiglitz notes, the USSR's industrial production under Nazi occupation fell only $24 \% .^{6}$

A key aspect of the Putin Plan was to replace the deeply entrenched mentality of the Soviet system with an ideology appropriate to the needs of a democratic and globally competitive Russia. This new ideology was referred to as 'sovereign democracy'.

Sovereign democracy, according to Putin's former deputy chief of staff and long time associate, Vladislav Surkov, describes Russia's optimal political system-one that would allow the current generation to link the positive experiences of the Soviet past to the post-Soviet values that Russia needed to succeed in an economically integrated world. To achieve this goal, Surkov argued that the present generation must believe that it was the Russian people themselves who had rejected the Soviet system and embraced a democratic, European future. By casting the fall of communism as a victory of the Russian people, rather than a defeat of their old social system, sovereign democracy would allow Russians of all generations and political persuasions deal with the past in a sober and respectful manner, while simultaneously helping them to move beyond it.

Surkov reasoned that the ability to define the past on their own terms would not only foster public unity; it would also help the country to pursue reforms in a manner consonant with its own political culture. To sum up Surkov's view: to become a sovereign country Russia must become economically competitive; to be economically competitive it must be governed democratically, which means in a manner that reflects the traditions and values of the Russian people. $^{7}$

\footnotetext{
${ }^{3}$ Nicolai N. Petro, "The Great Transformation: How the Putin Plan Altered Russian Society", ISPI Policy Brief no 132 (Institute for the Study of International Politics, Milan, Italy), May 2009, https://papers.ssrn.com/sol3/papers.cfm?abstract_id=1955176 (accessed 16 June 2009).

${ }^{4}$ Yuri Kolesov, "The Shadow of Judgement", Vremya novostei, 19 October 2004. Cited in Johnson's Russia List no 8416,

http://www.cdi.org/russia/johnson/ (accessed 28 October 2004); Mikhail Barshchevsky, "Sudya po vsemu", Rossiiskaya gazeta, 19 February

2013, http://www.rg.ru/2013/02/19/lebedev.html (accessed 26 February 2013).

5 "Vserosiiskii s'ezd sudei", Kremlin.ru, 6 December 2016, http://kremlin.ru/events/president/news/53419 (accessed 16 December 2016).

${ }^{6}$ Joseph E. Stiglitz, Globalization and Its Discontents_(New York: W. W. Norton \& Co., 2002): 143.

${ }^{7}$ Vladislav Surkov, "Russkaya politicheskaya kultura: vzglyad iz utopii", Kreml.org, 8 June 2007,

http://www.kreml.org/opinions/152440881?mode=print> (accessed 16 June 2007).
} 
The Putin Plan was spectacularly successful in restoring the Russian economy, and along with it Russia's sense of well-being and confidence in the future. In 1999 Russian annual GDP per capita was 1,334 dollars. At its height at the end of 2012, it was 15,409 dollars--an eleven fold growth. ${ }^{4}$ In 2001, 27.3\% of Russians lived below poverty. Ten years later it was below the EU average $(16 \%) .{ }^{8}$ The combination of a robust social safety net, official unemployment of $5.2 \%$, and an annual inflation rate at 2.5\%, with which Russia entered 2018 goes a long way to explaining the ease with which Putin won re-election to a fourth term, even as economic growth has slowed dramatically during this third presidential term due to the imposition of external sanctions. ${ }^{9}$

\section{The Foreign Policy Implications of the Putin Plan}

As mentioned, the Putin Plan also had a specific foreign policy purpose - ending Russia's dependence on external powers. Putin's first foreign policy review, completed in June 2000, came to the conclusion that Russia was unable to adequately defend its national interests, because its dependence on foreign loans translated into a constraint on its sovereignty. Only by achieving economic independence could Russia have a relationship of equals with the West.

In addition, according to Surkov, the idea of sovereign democracy implied that all nations should be free to choose their own social and political systems. Thus, from the outset, it presumes that multipolarity in international relations is to be preferred and that hegemony, be it military, economic, or cultural, would inevitably be a source of global instability and a potential threat to Russia. 'We sometimes hear', Surkov wrote, 'that no one is interested in taking away our sovereignty (or that this is unreal), but the universal and daily need for resources and security is so great, and our supply of these is so rich, that excessive complacency here hardly seems appropriate'. ${ }^{10}$

Because the Putin Plan and sovereign democracy evolved simultaneously, Russia's economic success, the restoration of state capacity, and the return to certain pre-Soviet traditions all came to be seen as tied together. Originally envisioned as a means to restore Russia to the broader European family, albeit on its own terms, sovereign democracy, as it later turned out, could also serve as a framework for Russia's burgeoning relations with non-Western powers.

\section{Russia Loses Faith in the West}

Despite a long tradition of suspicion of the West, capped by more than a half century of indoctrination by the Soviet regime, the peaceful collapse of the Soviet Union and dismantling of the Warsaw Pact seemed to presage an end to Cold War divisions. The first inklings that this would not be, were revealed by the eastward expansion of NATO in the late 1990s.

\footnotetext{
${ }^{4}$ Ben Aris, "Moscow Blog: A tale of two countries - Russia vs Ukraine", bne Intellinews, 13 July 2017, http://www.intellinews.com/moscowblog-a-tale-of-two-countries-russia-vs-ukraine-1h17-125236/?source=ukraine (accessed 1 August 2017).

${ }^{8}$ Jon Hellevig, “Russia's Good Fortune: The Flat Tax Reform”, Russia Blog (archive), 28 March 2007, http://archive.is/3Upm (accessed 16 April 2007).

9 "Russian economy under Putin: Quality of life tripled, foreign debt fell 75\%" RT.com, 27 January 2018, https://www.rt.com/business/417135putin-presidency-economic-growth-russia/ (accessed 30 January 2018).

${ }^{10}$ Vladislav Surkov, "Natsionalizatsiya budushchego", Ekspert no 43, 20 November 2006,

http://expert.ru/expert/2006/43/nacionalizaciya buduschego/ (accessed 19 December 2006).
} 
The exact nature of what was agreed to then is still being hotly debated more than a quarter century later. Those involved in the negotiations on the Russian side insist that, on the eve of the collapse of the Berlin Wall, all the principals agreed that the alliance would not be expanded even 'an inch to the East'. ${ }^{11}$ Many, though not all, of those involved on the American side have a different recollection. ${ }^{12}$ Whatever the reality, NATO expansion has become symptomatic of the broader misunderstandings that have come to plague the post-Cold War era.

Despite its lingering disappointment with NATO expansion, however, it is important to point out that during the early 2000s Russia still saw itself as part of the Western community of nations. In February 2000, when Putin was asked whether Russia was once again going to try and find its own 'special path', he famously replied: 'There is nothing to find-everything has already been found. It is the path of democratic development. Of course, is an extremely diverse country, but we are part of Western European culture. This is, in fact, our value. Wherever our people may live, in the Far East, or in the South, we are Europeans." ${ }^{13}$ For many in government. EU membership, at some point down the road, was deemed a foregone conclusion, a view the director of policy planning at the Russian Ministry of Foreign Affairs clung to even as late as December $2010 .^{14}$

Yet, even in that early interview, Putin hinted that much would depend on how Europe responded to Russia's aspirations. When his interviewer sarcastically remarked that, 'All that's left now, is for Europe to agree', Putin replied: 'We will strive to remain where geography and our spirit have placed us, but if we are pushed out, then we will be forced to seek other ties, and to bolster ourselves. That much should be obvious'. ${ }^{15}$

Russia's sense of aggrievement at NATO and the West became very apparent in February 2007, at the annual Munich Security Conference. In unusually candid language for a head of state, Putin laid out why he thought America's 'unipolar moment' could not last, and urged his audience to consider whether the 'absolute security' that America sought was even possible in the modern world. He suggested that participants think about creating a new architecture of global security, one that would accommodate the many new international actors coming onto the world stage. The United States, Putin acknowledged, would obviously be first among equals in this new world, but no longer the global hegemon. ${ }^{16}$

Putin's Munich speech was widely criticized in the West. After this speech, many observers, especially in the United States, saw Putin as anti-Western and openly welcomed his successor in

\footnotetext{
${ }^{11}$ See M. E. Sarotte, “A Broken Promise?” Foreign Affairs, 93 no 5 (September/October 2014), https://www.foreignaffairs.com/articles/russiafsu/2014-08-11/broken-promise (accessed 16 December 2014); Uwe Klussmann et al., "Did the West Break Its Promise to Moscow?” Spiegel, 26 November 2009, http://www.spiegel.de/international/world/nato-s-eastward-expansion-did-the-west-break-its-promise-to-moscow-a-663315.html (accessed 16 December 2009). For a thorough overview of the documentation, see Svetlana Savranskaya and Tom Blanton, "NATO Expansion: What Gorbachev Heard", National Security Archive, Briefing Book \#613, 12 December 2017, https://nsarchive.gwu.edu/briefing-book/russiaprograms/2017-12-12/nato-expansion-what-gorbachev-heard-western-leaders-early (accessed 30 January 2018).

${ }^{12}$ Jack F. Matlock, Jr., "NATO Expansion: Was There a Promise?” JackMatlock.com, 3 April 2014, http://jackmatlock.com/2014/04/natoexpansion-was-there-a-promise/ (accessed 11 June 2014).

${ }^{13}$ Roy A. Medvedev, Vremya Putina (Moscow: Vremya, 2014), 533, https://biography.wikireading.ru/187108 (accessed 6 June 2018).

${ }^{14}$ Alexander Kramarenko, "5 Reasons Why Russia Could Join NATO”, Moscow Times, 9 December 2010, https://themoscowtimes.com/articles/5-reasons-why-russia-could-join-nato-3106 (accessed 16 June 2011).

${ }^{15}$ Medvedev, Vremya Putina, 533.

${ }^{16}$ Vladimir Putin, "Vystuplenie i diskusii na Miunkhenshoi konferentsii po voprosam politiki bezopasnosti”, Kremlin.Ru, 10 February 2007, http://www.kremlin.ru/text/appears/2007/02/118109.shtml (accessed 16 June 2007).
} 
office, Dmitry Medevedev. ${ }^{17}$ That Medvedev did indeed come to office with an agenda of rapprochement with the West, is suggested by his selection of Germany for his first official state visit as president, and his remarks to the German Bundestag, where he reminded his audience that 'Russian and European democracy share common roots. We share the same set of values and the same sources of law: Roman, Germanic and French law... We have a common history and we share the same humanitarian values. This common thinking is the foundation that enables us to speak not just the same legal or business language today but, I hope, also the same political language'. 18

The Russo-Georgian conflict that erupted just months after Medvedev's inauguration, however, put the final nail in the coffin of any possible closeness with the West. The West's indifference to the fact that the Georgian Army had initiated hostilities, and to the plight of thousands of South Ossetians streaming over Russia's border for protection, led to universal outrage in Russia. Many regime opponents, noted human right activists, and even jailed oligarch Mikhail Khodorkovsky, all voiced support for Russian intervention in Georgia. ${ }^{19}$

Prior to the events of August 2008, Russian elites tended to regard U.S. unilateralism as an unfortunate, but understandable overreaction to the shock of 9/11. After Georgia, they would come to see it as a new strategy of containment, directed against Russia.

President Medvedev responded to this new domestic consensus by listing five core principles that would henceforth guide Russian foreign policy:

- First: the primacy of the basic principles of international law.

- Second: Multipolarity. The pursuit of unipolarity is unacceptable.

- Third: Russia will not seek confrontation with any country, but will not isolate itself.

- Fourth: Russia's priority is to protect the life and dignity of Russian citizens, wherever they are, and to protect the interest of its business community abroad.

- Fifth: Russia, like other nations, has regions with which it has traditionally had especially cordial and privileged relations, and it will seek to expand these relations. ${ }^{20}$

Still, when Medvedev signed off on a new national security strategy the following May, it did not presage any fundamental shift in Russian foreign policy. It continued to emphasize the quality of life, economic growth, science and education, health care, culture, and preservation of the environment. Of seven indicators used to measure national security listed in article 112, only two dealt with military matters. ${ }^{21}$

\footnotetext{
${ }^{17}$ John McCain, "Vladimir Putin Is an Evil Man”, Wall Street Journal, 11 May 2018, https://www.wsj.com/articles/john-mccain-vladimir-putinis-an-evil-man-1525964549 (accessed 6 June 2018); 'The John B. Hurford Memorial Lecture with Michael McFaul', Council on Foreign Relations, 11 May 2018, https://www.cfr.org/event/john-b-hurford-memorial-lecture-michael-mcfaul (accessed 6 June 2018).

${ }^{18}$ Dmitry Medvedev, "Speech at Meeting with German Political, Parliamentary and Civic Leaders," Kremlin.Ru, 5 June 2008, http://en.kremlin.ru/events/president/transcripts/320 (accessed 6 June 2018).

19 "Russia's use of force in South Ossetia is justified, says party leader", Interfax, 10 August 2008, cited in Johnson's Russia List 2008-no 146, http://www.cdi.org/russia/johnson/ (accessed 25 August 2008); Fred Weir et al., "Roots of Georgia-Russia clash run deep", Christian Science Monitor, 12 August 2008, https://www.csmonitor.com/World/Europe/2008/0812/p01s08-woeu.html (accessed 16 August 2008); "Khodorkovsky odobril deistviya Medvedeva v Yuzhnoi Osetii", Obshchaya gazeta, 11 September 2008, http://og.ru:8080/news/2008/09/11/41296 (accessed 20 September 2008).

20 "Medvedev sets out five foreign policy principles in TV interview", BBC Monitoring, 31 August 2008, cited in Johnson's Russia List 2008-no 163, http://www.cdi.org/russia/johnson/ (accessed 4 September 2008).

21 "Strategiya natsionalnoi bezopasnosti Rossiiskoi Federatsii do 2020 goda, Polit.ru, 6 October 2009,

http://www.polit.ru/dossie/2009/05/13/security.html (accessed 16 October 2009).
} 
Moreover, in a foreign policy speech he gave in July 2010, Medvedev added a distinctly Western tilt to Russian foreign policy, when he said that Russia intends to pursue 'special modernisation alliances' with its main international partners - Germany, France, Italy, the European Union, and the United States - to create 'incentives for integration based on shared modernisation imperatives'. ${ }^{22}$ Eventually, but only later, a similar approach would be designed for China and India.

But when Putin was re-elected president in 2012, he signed off on a very different foreign policy concept, that shifted attention to the role that spiritual and cultural values play in world affairs. ${ }^{23}$

\section{Russia's Conservative Mission Civilisatrice}

Putin used the occasion of the annual meeting with leading Russia specialists in Valdai in 2013 to talk about the importance of traditional values in Russian foreign policy. ${ }^{24}$ There, for the first time, he went beyond his longstanding criticism of unipolarity to explain what values Russia stood for. It was a statement of Russia's mission to the world in the 21 st century.

Putin began by noting that countries cannot merely rely on foreign models; they must do everything in their power to preserve their own, distinct identities. 'Without [such] spiritual, cultural and national self-definition .... one cannot succeed globally'.

So, while Russia must be strong militarily, technologically, and economically, the most important components of national success, Putin argued, are the intellectual, spiritual, and moral state of its people. Russia's influence will depend on how much its citizens feel that they are one people, sharing a common history, common values, and common traditions.

Free markets alone cannot generate such a sense of unity. Neither can a laissez faire approach to government. What Russia needs, says Putin, is a creative synthesis of the best examples from the nation's history and intellectual past, gleaned from a variety of cultural, spiritual, and political perspectives. A diversity of sources is crucial, Putin told his audience, because Russia has, from its inception, been a multinational and multiconfessional state.

In fact, Putin argued, cultural pluralism is destined to be one of Russia's main contribution to global development. 'We have amassed a unique experience of interacting with, mutually enriching, and mutually respecting diverse cultures. Polyculturalism and poly-ethnicity are in our consciousness, our spirit, our historical DNA [исторический код]', says Putin. Russia's 'effervescent complexity' [цветущая сложность] he says, citing the nineteenth century

\footnotetext{
${ }^{22}$ Dmitry Medvedev, "Speech at meeting with Russian ambassadors and permanent representatives in international organisations", Kremlin.Ru, 12 July 2010, cited in Johnson's Russia List 2010-\#135, http://www.cdi.org/russia/johnson/ (accessed 8 October 2010). With this speech Medvedev confirmed the authenticity of a classified foreign policy memo, published by Russian Newsweek in May, entitled "Let the Sun Shine In." Konstantin Gaaze and Mikhail Zygar, "Pust' opyat' budet Solntse," Newsweek (Russia) 9 May 2010, http://perevodika.ru/articles/13593.html (accessed 6 June 2018). The full text of this document, "A Program for the Effective and Systematic Use of Foreign Policy Factors for Long Term Development of the Russian Federation," is available at http://www.flot2017.com/file/show/normativeDocuments/24231 (accessed 6 June 2018).

${ }^{23}$ Vladimir Putin, "Kontseptsiya vneshnei politiki Rossiiskoi Federatsii”, Ministry of Foreign Affairs, 12 February 2013, http://www.mid.ru/brp_4.nsf/0/6D84DDEDEDBF7DA644257B160051BF7F (accessed 16 June 2013).

${ }^{24}$ Vladimir Putin, “Zasedanie mezhdunarodnogo diskussionnogo kluba 'Valdai”, Kremlin.ru, 19 November 2013, http://kremlin.ru/events/president/news/19243(accessed 16 December 2013).
} 
conservative philosopher Konstantin Leontyev, is enhanced by the framework of Russian language, culture, and traditional religions, and define Russia's distinctiveness as a 'civilizationstate'. 25

Today, the greatest challenge to cultural pluralism emanates from the West, specifically from those parts of it that have rejected traditional cultural identity, even the values of Christianity that form the basis of Western civilization. The unipolar, monolithic and increasingly secular world that some in the West would seek to impose on others, says Putin, is 'a rejection ... of the natural diversity of the world granted by God... . [for] without the values of Christianity and other world religions, without the norms of morality and ethics formed over the course of thousands of years, people inevitably lose their human dignity'. Russia, he says, will defend these Christian moral principles, both at home and abroad. ${ }^{26}$

At Valdai, Putin officially declared that the post-Soviet era was over for Russia. Echoing the remarks of 19th century Russian foreign minister Alexander Gorchakov, Russia, he said that Russia is returning to itself, to its own past, while remaining open and receptive to the best ideas of both East and West. ${ }^{27}$

\section{Ukraine: From 'Priority Partnership' to War}

While alluding only briefly to the geopolitical ramifications of the traditionalist turn that he was proposing, Putin had already, back in 2011, committed Russia to the creation of a Eurasian Union, a project that he described as designed to 'move the Eurasian heartland from the periphery of global development to its center'. ${ }^{28}$ For him, clearly, Russia's great Slavic neighbor to the South, Ukraine, was to be a key player in this Union. Throughout his career, Putin has made no bones about his view that, while they may now be two separate nations, Russians and Ukrainians are essentially one people. ${ }^{29}$ To his mind, the struggles that Ukraine has endured since its independence, mirrored the struggles that Russia had undergone the previous decade, only exacerbated by Ukrainian nationalism.

As a result, political power in Ukraine alternated between its Eastern (Russophone) and Western (Ukrainophone) regions, each seeking to prevent the other side from implementing its maximum political and cultural agenda. The resulting political gridlock was Ukraine's way of avoiding civil war, which many believed would erupt if either side were to dominate completely, and turn its version of Ukrainian identity into a test of civic loyalty.

President Victor Yanukovych's removal from office on 22 February 2014 upset the delicate political balance between Galicia and Donbass, and was therefore perceived as a direct threat to the core interest of Russophone Ukrainians. Two-thirds of Donbass residents surveyed in April 2014 said they

\footnotetext{
${ }^{25}$ Putin seems to be echoing Jose Manuel Barroso, then president of the European Commission, who had earlier that year referred to Russia as "a civilization veiled as a nation". "Speech by President Barroso at the Russia-European Union - Potential for Partnership conference: Moving into a Partnership of Choice", Europa.eu, 21 March 2013, http://europa.eu/rapid/press-release_SPEECH-13-249_en.htm (accessed 16 June 2013 ).

${ }^{26}$ Putin, "Zasedanie".

${ }^{27}$ Gorchakov's recueillement as a theme in Russian diplomatic history is discussed by Andrei Tsygankov, Russia and the West from Alexander to Putin: Honor in International Relations (New York: Cambridge University Press, 2012), 137-155.

${ }^{28}$ Vladimir Putin, "Novyi integratsionnyi proekt dlya Evrazii", Izvestiya, 3 October 2011, https://iz.ru/news/502761 (accessed 16 October 2011).

29 "Bolshaya press-konferentsiya Vladimira Putina", Kremlin.ru, 14 December 2017, http://kremlin.ru/events/president/news/56378 (accessed 26 December 2017).
} 
regarded the Maidan as 'an armed overthrow of the government, organized by the opposition with the assistance of the West' ${ }^{30}$ Recent surveys suggest that that number has scarcely changed since the beginning of the conflict. ${ }^{31}$

The new authorities in Kiev's ham fisted efforts to revoke the language law passed by the Ukrainian parliament in 2012, which allowed the official use of local language in regions where at least ten percent spoke it, provoked a violent response in regions where Russian language and culture are seen as part of Ukrainian identity. With Russia's support, Crimea voted for secession from Ukraine, then annexation by Russia. In the easternmost segments of Donbass, the conflict still rages.

The crisis in Ukraine marks a crucial step in the emergence of what many are now calling 'the New Cold War'. While Western political leaders typically describe Russia's actions in Ukraine as offensive and a challenge to the post-war order, their Russian counterparts typically describe their actions as defensive, both in terms of preserving the rights of local residents, and in terms of preserving the country's vital strategic interests in the Black Sea. ${ }^{32}$ This division has been exacerbated by the approach that each side has taken in resolving this conflict. Although both Russia and the West says they want political and social stability in Ukraine, they disagree strongly about how that stability can be achieved.

By and large, Western leaders remain ignorant of, and indifferent to, the cultural differences within Ukraine, even though these differences once led professor Samuel P. Huntington to describe Ukraine as a 'cleft country', and to presciently single out Crimea as a region of particular contention. ${ }^{33}$ Today, most Western leaders simply assert that, if corruption is reduced and the economy grows, the cultural divisions of past centuries will simply fade away, and a new political and social consensus develop. Ambassador Kurt Volker, the latest U.S. special representative on Ukraine, takes this view to its most inane extreme, saying: "As I've said before, the only place in Ukraine where Russian-speakers are at risk is where there are Russian soldiers". 34

Russia, on the other hand, views post-Soviet Ukraine as a culturally fragmented society. Stability, it argues, can be achieved only if political authorities there accept the bi-cultural nature of Ukraine, and create a constitutional framework that grants the country's major cultural constituencies equal rights. ${ }^{35}$

\footnotetext{
30 “Mneniya i vzglyadi zhitelei you-vostoka Ukrainy: Aprel 2014", Zerkalo nedeli, 18 April 2014, https://zn.ua/article/print/UKRAINE/mneniyai-vzglyady-zhiteley-yugo-vostoka-ukrainy-aprel-2014-143598 .html (accessed 16 June 2014).

31 "Zhiteli Yuga Ukrainy schitayut Evromaidan perevorotom. . . ", Timer Odessa, 14 February 2017, http://timerodessa.net/news/jiteli yuga ukraini schitayut maydan perevorotom i veryat chto voyna na donbasse vigodna kievu 849 .html (accessed 16 April 2017); "Kazhdyi pyatyi zhitel Yuga i Vostoka podderzhivayut avtonomiyu okkupirovannogo Donbassa--opros", Institut massovoi informatsii, 4 July 2017, http://imi.org.ua/news/kojen-pyatiy-meshkanets-pivdnya-ta-shodu-pidtrimue-avtonomiyu-okupovanogo-donbasuopituvannya-2/ (accessed 16 July 2017). See also the explanation in footnote 51.

${ }^{32}$ Eduard Steiner, "Um zu überleben, muss Russland siegen”, interview mit Sergej Karaganow, Die Presse, 12 November 2017, https://diepresse.com/home/ausland/aussenpolitik/5318661/Um-zu-ueberleben-muss-Russland-siegen?from=suche.intern.portal (accessed 6 June 2018); Vladislav Surkov, "Odinochestvo polukrovki (14+)" Rossiya v globalnoi politike, 9 April 2018, http://www.globalaffairs.ru/print/globalprocesses/Odinochestvo-polukrovki-14-19477 (accessed 6 June 2018).

${ }^{33}$ Samuel Huntington, The Clash of Civilizations and the Remaking of World Order (New York, Simon and Schuster, 2007), 138. The U.S. Special representative on Ukraine, Kurt Volker, has taken this view to its most absurd extreme by saying "As I've said before, the only place in Ukraine where Russian-speakers are at risk is where there are Russian soldiers" Волкер: единственное опасное место в Украине - где находятся российские солдаты Sharij.net, 13 April 2018, https://sharij.net/114485 (accessed 6 June 2018).

34 "Volker: edinstvennoe opasnoe mesto v Ukraine—gde nakohodiatsy rossiiskie soldaty", Sharij.net, 13 April 2018, https://sharij.net/114485 (accessed 6 June 2018).

${ }^{35}$ Christopher Harress, "Vladimir Putin Urges Donetsk And Luhansk To Remain Part Of Ukraine", International Business Times, 6 June 2015 , http://www.ibtimes.com/vladimir-putin-urges-donetsk-luhansk-remain-part-ukraine-1955758 (accessed 6 June 2015) ; "Russia FM suggests
} 
These constitutional reforms are laid out in a comprehensive political settlement known colloquially as the Minsk Accords. ${ }^{36}$ By institutionalizing regional autonomy, the Accords are meant to guarantee a modicum of regional political and cultural pluralism within Ukraine. It is this aspect of the Accords that Ukrainian nationalists object to most strongly, since they fear that it will undermine national unity. $^{37}$

This conflict has fundamentally altered Russia's foreign policy toward Ukraine. Instead of seeking a 'priority partnership' with Ukraine as it did in 2012, Russia's most recent national security documents now say that ties must be based on 'mutual respect' and strict attention to each other's national interests. ${ }^{38}$ In Ukraine many have interpreted this as a sign that Russia is turning its back on Ukraine, a prospect that some view with delight, others with alarm because of its potentially devastating consequences for the Ukrainian economy. ${ }^{39}$

The fallout from this conflict has also reinforced negative stereotypes toward the West in Russia, where many see events in Ukraine as the logical culmination of Western policies aimed at regime change in the countries of the former Soviet Union. From this perspective, Ukraine is not the issue that must be resolved so that relations with the West can improve. Rather, it is an issue that, if resolved, will show that the West is sincere about wanting better relations with Russia. Since the chances of this happening are seen as slim to non-existent, some influential Russian policy analysts, like the aforementioned Vladislav Surkov, have recently suggested that, after four centuries of fruitless efforts, Russia's efforts to be seen as part of European civilization may now be over. ${ }^{40}$

From this perspective, the root problem in relations with the West has been the animosity western elites have displayed for centuries, first toward the Russia Empire, then toward the Soviet Union, and now toward post-Soviet Russia. ${ }^{41}$ Consequently, as Russia has begun to emphasize its own distinctive values, tensions with the West have inevitably heightened. These distinctive values derive in no small measure from the unique role played by the Russian Orthodox Church.

\section{Russia's Conservative Restoration: Soft Power and the Orthodox Church}

After he was elected as president for a third time in 2012, Putin undertook the customary foreign policy review. ${ }^{42}$ According to this document, the global balance of power is clearly shifting from the

Ukraine dialogue under OSCE auspices”, Fox News, 1 May 2014, http://www.foxnews.com/world/2014/05/01/russia-fm-suggests-ukrainedialogue-under-osce-auspices.html (accessed 6 June 2018).

36 "Package of Measures for the Implementation of the Minsk Agreements", OSCE, 12 February 2015, http://www.osce.org/cio/140156, points 9 and 10 (accessed 16 February 2016).

${ }^{37}$ Katharine Quinn-Judge, "To Reunite Ukraine, Kyiv Must Overcome Its Own Prejudices”, International Crisis Group, 20 March 2018, https://www.crisisgroup.org/europe-central-asia/eastern-europe/ukraine/reunite-ukraine-kyiv-must-overcome-its-own-prejudices (accessed 16 April 2018).

${ }^{38}$ Ukaz Prezidenta Rossiiskoi Federatsii ot 30.11.2016 № 640 “Ob utverzhdenii Kontseptsii vneshnei politiki Rossiiskoi Federatsii”, Official Government Internet Portal for Legal Information, 1 December 2016, http://publication.pravo.gov.ru/Document/View/0001201612010045 (accessed 16 June 2017).

${ }^{39}$ Nicolai N. Petro, "Why Russia and Ukraine Need Each Other", Russian Politics, vol.1. No, 2, June 2016, 184-202,

http://booksandjournals.brillonline.com/content/journals/10.1163/24518921-00102004;jsessionid=2nsjuukv6xa0v.x-brill-live-03 (accessed 6 June 2018).

${ }^{40}$ In "Odinochestvo polukrovki” Rossiya v globalnoi politike.

${ }^{41}$ In his latest essay, Vladislav Surkov laments the 'end of Russia's epic journey to the West, the demise of the multiple but fruitless attempts to become part of European civilization'. "Odinochestvo polukrovki”, Rossiya v global'noi politike, 9 April 2018,

http://www.globalaffairs.ru/print/global-processes/Odinochestvo-polukrovki-14-19477 (accessed 1 May 2018).

42 "Concept of the Foreign Policy of the Russian Federation", Ministry of Foreign Affairs of the Russian Federation, 18 February 2013 ,

http://www.mid.ru/en/foreign policy/official documents/-/asset_publisher/CptICkB6BZ29/content/id/122186 (accessed 1 May 2018). 
West to the Asia-Pacific region. Western powers will seek to prevent this, resulting in heightened regional tensions, lower economic growth rates, and the fracturing of long established trade associations and alliances.

Because the danger of global chaos along this trajectory is so high, Russia must do everything in its power to forge a more pluralistic international order. One of its main tools for doing so will be Russian soft power, whose appeal stems largely from the fact that, in contrast to American soft power, it does not envision the new world order as merely an extension of American values. ${ }^{43}$

But since Russia has begun to promote a more values-oriented foreign policy, it has also argued that certain values, if adopted as principles of behavior, are more congenial to international order than others. These are not the values of any one community or culture, but they do exist, and can be gleaned from the values shared by the world's largest and oldest religious communities-Judaism, Christianity, Islam, and Buddhism. ${ }^{44}$

But if Russian soft power is about cultural pluralism, how does one account for the increasingly prominent role of the Russian Orthodox Church, both at home and abroad? According to Russian officials, there is less of a tension between the two than might appear. Many ancient civilizations of the Middle East and North Africa, they say, are 'returning to their roots'. Such a return does not presume values developing in isolation, but rather the forging a common values framework, which all the world's major religions have in common.

Russia's soft power is thus conceived around the premise that a better world order can only be forged around respect for all values, even mutually incompatible ones. It is thus tied not to any distinct set of values which are then projected globally by a specific nation, but to cultural diversity itself. $^{45}$ To use Isaiah Berlin's terminology, while American soft power aspires to positive freedom someday replacing the more limited notion of negative freedom, Russian soft power sees culture as setting firm boundaries on both negative and positive aspirations for freedom. ${ }^{46}$

Russia's new emphasis on values generally, and on religious values in particular, has led to numerous areas of friction with the West. The first involves the very nature of the international order. Since the rise human rights and democracy as explicit U.S. foreign policy objectives in the 1970s, western political leaders have often argued that Western foreign policy ought mirror its domestic politics. That is because, according to the popular theory known as 'democratic peace theory', democracies do not go to war with each other. States that promote democracy are

\footnotetext{
${ }^{43}$ On the relationship of American exceptionalism to the spreading of American values, see Dick Cheney and Liz Cheney, "Restoring American Exceptionalism", Wall Street Journal, 28 August 2015, https://www.wsj.com/articles/restoring-american-exceptionalism-1440801129 (accessed 16 June 2016); and Hillary Clinton, "Why America Is Exceptional", Time, 13 October 2016, http://time.com/4521509/2016-election-clintonexceptionalism/?xid=homepage (accessed 16 December 2016). For a critique, see Akhilesh Pillalamarri, "The Bitter Fruits of Wilsonianism”, The American Conservative, 31 March 2017, http://www.theamericanconservative.com/articles/the-bitter-fruits-of-wilsonianism/?print=1; and Andrew J. Bacevich, “Angst in the Church of America the Redeemer”, Salon, 25 February 2017, http://www.salon.com/2017/02/25/angst-in-thechurch-of-america-the-redeemer_partner/ (accessed 16 June 2017).

44 "Poseshcenie Sretenskogo monastyrya_Prezident Rossii", Kremlin.ru, 25 May 2017, http://kremlin.ru/events/president/news/54573 (accessed 6 June 2018).

45 "Concept of the Foreign Policy of the Russian Federation", Ministry of Foreign Affairs, 18 February 2013, paragraphs 20 and 39 (m).

46 "Two Concepts of Liberty" was Berlin's inaugural lecture as Chichele Professor of Political and Social Theory at Oxford University, delivered 31 October 1958. It is available on line, with the author's annotations, at The Isaiah Berlin Virtual Library,

http://berlin.wolf.ox.ac.uk/published_works/tcl/ (accessed 16 June 2007). Berlin saw both types of liberty as susceptible to extreme interpretations. Negative freedom--to the failure to grasp that "democratic self-government is a fundamental human need, something valuable in itself". Positive freedom--to paternalistic abuse by elites willing to runs rough-shod over pluralism and diversity. Isaiah Berlin, Five Essays on Liberty (New York: Oxford University Press, 2004), 1-2.
} 
therefore promoting a morally desirable international order, whereas states that object to such efforts are deemed immoral.

A second source of friction stems from the frustration of some western governments with the extent to which international institutions are willing to promote democracy and human rights. The United States and its allies have sought ways around these institutions by asserting that western values are the de facto, if not yet de jure, international standard. Thus, when several western nations decide to act in concert, as in the case of Iraq or Syria, it is said that they do not require any explicit mandate from the United Nations. This has been a source of considerable friction between Russia and the West.

A third source of friction is the very fact that the Russian Orthodox Church is so closely partnered with the state. With respect to Russian foreign policy, the ROC supports the government's objective of creating a 'congenial international order' that, it believes, it will assist the Church it in its threefold salvific mission--to save individual souls, to save all national cultures that have been baptized into Christ, and to save all mankind. Needless to say, this is as far from the doctrine of separation of Church and State, as East is from West. ${ }^{47}$

The values-based contours of the present East-West conflict can be readily seen in Russia's opposition to the notion that Western cultural values are the standard for international behavior. Russia regards this as unilateralism, and believes that a multipolar world order based on pluriculturalism is a more desirable alternative.

Pluriculturalism asserts that there is an inherent ('God-given' according to Vladimir Putin) value to diversity among nations. ${ }^{48}$ Pluriculturalism is distinct from multiculturalism, which values diversity within nations. Russia assigns diversity within nations a lower priority than it does diversity among nations. By contrast, Western states typically give greater weight to diversity within nations (the rights of the individual), whereas among nations, they seek to subordinate national cultural differences to standards such as human rights, that express modern western values.

But while some political friction fallout from such a pronounced conflict of visions is inevitable, it should be possible to prevent this conflict of ideals from spilling over into outright ideological hostility. One way to do so might be to look at this distinction in a broader context.

Russian pluriculturalists argue that national cultural distinctions should impose certain limits on a nation's foreign policy ambitions. It is worth noting that this was, in fact, the original meaning of 'American exceptionalism' — the idea, as John Quincy Adams put it, that America does not go overseas 'in search of monsters to destroy'. ${ }^{49}$

Nor is the Orthodox Church's moral framework quite as 'anti-modern' or 'anti-liberal' as it appears to be at first blush. The writings of senior Russian clergy are typically quite nuanced,

\footnotetext{
${ }^{47}$ Nicolai N. Petro, “The Orthodox Church", in Andrei Tsygankov, ed., The Routledge Handbook of Russian Foreign Policy (London: Routledge, 2018), 217-232.

${ }^{48}$ Putin, "Zasedanie".

${ }^{49}$ John Quincy Adams, "She Goes Not Abroad in Search of Monsters to Destroy", The American Conservative, 4 July 2013,

http://www.theamericanconservative.com/repository/she-goes-not-abroad-in-search-of-monsters-to-destroy/ (accessed 16 August 2013).
} 
arguing that both the Enlightenment and liberalism were valuable and progressive social ideals in their day, but that having abandoned the moral framework provided by the Christianity they have deformed and become monstrous. ${ }^{50}$

What the Orthodox Church does reject, and this wholeheartedly, is the cultural dominance of secularism. The fact that contemporary western societies tend to regard secularism, along with modernity and liberalism, as forming the quintessential western trinity of values, is something that the Russian Orthodox Church is especially keen to reverse.

Finally, one should never lose sight of the fact that the Church sees itself, first and foremost, as a supernatural actor -- the manifestation of the Holy Spirit in history. Political battles have scant meaning when one is competing for the very soul of mankind. This latter is the only struggle that has meaning for the Church. It is its very raison d'etre, and its outcome will not be decided by the struggle among nations, but by the struggle that goes on within men's souls.

But while the focus on traditional morality and Orthodox values might appeal domestically, as a foreign policy strategy its allure seems limited. Among Russia's immediate neighbors, for example, the response has been mixed. While there are still many who view the Soviet era with nostalgia, and regard the break of the USSR as more harmful than beneficial (sometimes by wide margins, as in Armenia, Kyrgyzstan, Russia, and portions of Ukraine), it is not at all clear that the Orthodox Church's conservative social vision appeals to the same degree. ${ }^{51}$

The overall effectiveness Russian soft power is therefore best gauged in the context of a Russia's proposed foreign policy alternative --civilizational realism

\section{‘Civilizational Realism': Russia's New Approach to International Relations?}

The previous discussion of values and morality sheds a rather different light on some widely held Western assumptions about Russian foreign policy. The first, is that Russia rejects the post-Cold War international order. This is not correct. Russia fears global chaos, and believes that efforts to preserve the global hegemony of the West will exacerbate tensions and lead to a breakdown of the international order. That is why Russia places such a high value on the international order. To the extent that it is rooted in the supremacy of international law and under the guidance of UN Security Council, it mitigates chaos. ${ }^{52}$

\footnotetext{
${ }^{50}$ (Ryabykh), Hegumen Philip (Ryabykh), "Russky mir-eto tsivilizatsionnaya obshchnost. . .”, 17 June 2010, Patriarchia.ru, http://www.patriarchia.ru/db/print/26208.html (accessed 6 June 2018).

${ }^{51}$ Neli Esipova and Julie Ray. "Former Soviet Countries See More Harm From Breakup". Gallup.com, 19 December 2013.

http://www.gallup.com/poll/166538/former-soviet-countries-harm-breakup.aspx?version=print (accessed 16 June 2014). "Dazhe bez Kryma i

Donbassa storonnikov SSSR v Ukraine okazalos bolshe chem protivnikov", Narodnyi correspondent, 16 March 2018,

http://nk.org.ua/ukraina/daje-bez-kryima-i-donbassa-storonnikov-sssr-v-ukraine-okazalos-bolshe-chem-ego-protivnikov-

136050?utm_referrer=https\%3A\%2F\%2Fzen.yandex.com (accessed 16 April 2018).

${ }^{52}$ As Dmitry Trenin notes, Russia has offered no alternative design to what exists today and no comprehensive reform blueprint. It is not the world order as such that Moscow has challenged, but the U.S. domination of that order. He illustrates by saying that "the UN Security Council has always been the right model for the Russians, while the NATO-Russia Council has not for this very reason", "Looking out Five Years: What Should Washington and Its European Allies Expect From Moscow?" Carnegie Moscow Center, 24 August 2017,

http://carnegie.ru/commentary/72813 (accessed 16 September 2017).
} 
How does Russia reconcile this with the annexation of Crimea, support for the rebellion in Donbass, and allegations that it is engaging in "hybrid warfare" against the US and Europe? Primarily through denials and legal counterarguments for its actions.

Russia's legal position on Crimea is that, although the Ukrainian constitution prohibits local referenda on secession, this is trumped by under the UN Charter (article 1), which stipulates that people have the right to self-determination. Russia changed its position on this following the decision of July 22, 2010 by the International Court of Justice to recognize Kosovo's independence from Serbia. At the time the US State Department filed a brief in support of Kosovo, arguing that 'there was no general rule [because] these were political acts'. They were therefore worthy of recognition because declaring independence had created a new 'political reality' in the region. ${ }^{53}$

Russia, which had originally opposed this ICJ ruling, later found it quite congenial for its approach to Ukraine. It now argues that Ukrainians living in Crimea and Donbass have the same right to determine their allegiance that Kosovars did when they were living in Serbia, and that the Crimean referendum of March 16, 2014 overwhelmingly ratified that decision.

The vast majority of international legal experts, however, argue that this referendum was illegitimate because Russia facilitated the ability of Crimean authorities to hold such a referendum with masked military intervention. ${ }^{54}$ In response, Russia makes two counterarguments. First, on the charge that the presence of Russian troops invalidates the referendum, it argues that responsibility for law and order at the polling stations was born by local self-defense forces and people's volunteers, and that the Russian troop presence ensured only that the referendum could take place. ${ }^{55}$

Second, to the point that the Ukrainian Constitution states that the separation of a part of the country's territory cannot be subject to a local referendum, Crimean officials point out that the authorities in Kiev had already revoked the acting Ukrainian Constitution on February $21^{\text {st }}$ and reinstated the 1996 constitution. This was done in one day, without any judicial review, and as such was illegal. The Crimean government responded by assuming control until 'constitutional order' was restored in Kiev, and began negotiations with Kiev. ${ }^{56}$ When those failed, Crimean

\footnotetext{
${ }^{53}$ Harold H. Koh, “The International Court of Justice's Advisory Opinion on Kosovo's Declaration of Independence” U.S. Department of State (archived), FPC Briefing on 22 July 2010, https://2009-2017-fpc.state.gov/145040.htm (accessed 16 June 2011).

${ }^{54}$ Notable dissenters include Reinhard Merkel, professor of law and legal philosophy at the University of Hamburg, "Die Krim und das Völkerrecht. Kühle Ironie der Geschichte", Frankfurter Allgemeine Zeitung, 7 April 2014. http://www.faz.net/aktuell/feuilleton/debatten/diekrim-und-das-voelkerrecht-kuehle-ironie-der-geschichte-12884464.html?printPagedArticle=trueno pageIndex 2; Michael Geistlinger, professor of law at the University of Salzburg (Austria), "Der Beitritt der Republik Krim zur Russländischen Föderation aus der Warte des Selbstbestimmungsrechts der Völker”, Archiv des Völkerrechts, 52, no 2 (June 2014): 175-204; and Peter Ørebech, professor of law at the University of Tromsø (Norway), "International law and the Crimea", Radikal Portal, 8 June 2017. https://is.gd/IzeAsd. Noted American jurist Eric Posner has argued that the equities in this case, as in other cases of separatism, are "complicated", and that "the secession of Crimea, good or bad, is now an accomplished fact". "What to do About Crimea. Nothing" Slate, 27 March 2014.

http://www.slate.com/articles/news_and_politics/view_from_chicago/2014/03/sanctions_against_russia_why_everything_we_are_doing_about_c rimea_is_completely.html (accessed 16 February 2018).

${ }^{55}$ Merkel, "Die Krim und das Völkerrecht".

${ }^{56}$ The trial in absentia of former president Viktor Yanukovych is bringing to light more and more new details about the actions of the Ukrainian government during those days. Parliamentarian Nestor Shufrich was delegated to head negotiations with the new Crimean leadership. On 28 February 2014 he met with Crimean leaders and worked out an agreement that would keep Crimea in Ukraine by restoring the Crimean constitution of 1992, without the Crimean presidency. A delegation was scheduled to arrive on Monday, March $3^{\text {rd }}$ to work out the final text. By Monday morning, however, the Prosecutor General Makhnitsky had received orders to issue an arrest warrant for Crimean leaders Konstantinov and Aksyonov, to which Aksyonov responded by taking over control of government institutions in Crimea. Taras Kozub, "V vozdukhe povis
} 
authorities acted in accordance with their view that Crimean sovereignty had been restored to the status quo ante 1992, and this was the issue put to the people in the March referendum. ${ }^{57}$

For Russia, the accusation of clandestine support for the rebellion in Donbass, and hybrid warfare against the West are not legal, but political in nature. With respect to Donbass, Russia has consistently rejected all accusations that its troops are fighting there, although it does acknowledge assisting in humanitarian relief efforts there. The same is true of Western accusations of cyber warfare and the intentional manipulation of elections. Moreover, in the latter instance, Russia argues that it has long been a proponent of the need for international treaties to safeguard countries from such interference. ${ }^{58}$

The bottom line is that Russia is not rejecting the traditional international framework of conflict resolution. Rather, by making its counterarguments within the same framework, it is reaffirming its importance. This is the antithesis of the Soviet approach, which regarded the the entire 'bourgeois' legal and international system as illegitimate, even though in practice it often continued to abide by it. ${ }^{59}$

A second common assumption is that Russia seeks to undermine the 'liberal U.S. led order'. In fact, Russia expects the US to remain the leader of the liberal, western model of global development. This model, however, must learn to co-exist with other models. Russian analysts often make the analogy to institutional religions. These can coexist peacefully, so long as they do not seek to impose their view of the Truth on others, and respect each other's value to humanity's cultural diversity. As Russia sees it, in the future there will be multiple centers of power, each believing itself no less moral than any other. Clinging to a messianic view of liberalism and American exceptionalism only serves to isolates the West, says Russia, and while U.S. leadership is likely to fade in a more pluralistic world, liberalism need not be dragged down along with it.

Russia, therefore, sees itself as that part of the West that understands the futility of 'liberal fundamentalism', to use Boris Mezhuev's felicitous phrase, and therefore seeks to establish a framework of global leadership around the values that the West shares with non-Western states. Prominent political theorist Mezhuev has called this 'civilizational realism'. ${ }^{60}$

Civilizational realism differs from classical realism in that it recognizes the importance of values in international affairs. It differs from classical liberalism in that it sees value in the diversity of cultural communities, as well as individuals. Russia's approach can therefore best be described not

\footnotetext{
vopros: kto sdal Krym?" Vesti, 8 February2018, https://vesti-ukr.com/strana/276905-v-vozdukhe-povis-vopros-kto-sdal-krym-kak-prokhodiliperehovory-kieva-s-poluostrovom-v-fevrale-2014 (accessed 16 February 2018).

57 “Crimea referendum: What does the ballot paper say?” BBC News, 10 March 2014, http://www.bbc.com/news/world-europe-26514797 (accessed 16 June 2014).

58 Jeremy Kirk, "Russia Pushes for UN Resolution on Cyberspace", PC World, 3 October 2011.

https://www.pcworld.com/article/240983/russia pushes for un resolution on cyberspace.html (accessed 16 June 2012); John Markoff and

Andrew Kramer, "U.S. and Russia Differ on a Treaty for Cyberspace”, New York Times, 27 June 2009,

https://www.nytimes.com/2009/06/28/world/28cyber.html (accessed 16 July 2009).

${ }^{59}$ The classical ideological statement of this approach is Leon Trotsky's “Their Morals and Ours", The New International, Vol.IV No.6, June 1938, pp.163-173, https://www.marxists.org/archive/trotsky/1938/morals/morals.htm (accessed 6 June 2018); for its application to international law, see Evgeny Pashukanis, "International Law", (1925) Marxists Internet Archive,

https://www.marxists.org/archive/pashukanis/1925/xx/intlaw.htm (accessed 6 June 2018).

${ }^{60}$ Boris Mezhuev, "O realizme i beregakh tsivilizatsii", Vzglyad, 13 January 2017, http://www.vz.ru/columns/2017/1/13/853243.print.html (accessed 16 June 2017).
} 
as opposition to liberalism, but as a different form of liberalism, one that is divorced from Western hegemony and open to non-western traditions and influences. ${ }^{61}$

We can now better understand the peculiar emphasis that Russia has placed on the spiritual and cultural aspects of international politics since 2013. There are both conceptual and practical reasons for this. Conceptually, Russia's cultural/moral/religious image--its 'soft power'-- has emerged as an important resource in promoting domestic unity, as anticipated by the Putin Plan in the early 2000s. ${ }^{62}$

Additionally, it is now seen as a net benefit for Russian foreign policy. If soft power is thought of as the use of religious and/or cultural affinity to achieve foreign policy objectives, then many of Russia's neighbors remain quite receptive to Russian soft power. Sometimes, as in Ukraine, Georgia, Bulgaria, and Moldova this is manifested in a 'love-hate' relationship that keeps Russia at the center of public attention, even as national elites desperately seek to distance their country from Russian cultural influence. ${ }^{63}$

A November 2016 nationwide survey of Ukrainians revealed that $26 \%$ agree that Ukrainians and Russians are, as Putin likes to say, 'one people', while 51.1\% say they are 'brother nations' ${ }^{64} \mathrm{~A}$ December 2017 survey revealed that a plurality, 36\%, still regard the collapse of the Soviet Union as negative thing. ${ }^{65}$ And although the numbers looking to some type of economic and political alliance with Russia and Belarus have fallen sharply since 2014, after nearly four years of warfare they still hover around $20 \%$ nationwide, largely because of broad support in the Eastern and Southern Ukraine. $^{66}$

It is also important to note that surveys in Ukraine most likely understate the level of support for 'pro-Russian' views. First, because they do not include Crimea and the rebel regions of Donbass. Were they included, Kiev based political analyst Kost' Bondarenko believes it would shift the national results by as much as $10-15 \% .{ }^{67}$ Second, because, increasingly, people in the East and South of Ukraine are reluctant to express their opinions to strangers. ${ }^{68}$

\footnotetext{
${ }^{61}$ International relations theorist Giorgio Shani refers to this as establishing a 'post-Western' understanding of security which is tolerant of different conceptions of peace, freedom and dignity in different cultural traditions. On such a basis, different conceptions of security and IR would invariably arise. "Interview - Giorgio Shani”, E-International Relations, 2 January 2017, http://www.e-ir.info/2017/01/02/interviewgiorgio-shani/ (accessed 16 June 2017).

${ }_{62}$ Petro, "The Great Transformation".

63 "Moscow Clout Rises as Bulgaria, Moldova Elect Pro-Russia Leaders", Voice of America, 14 November 2016, https://www.voanews.com/a/analysis-pro-russia-trends-in-bulgaria-moldova/3595445.html (accessed 16 December 2016).

64 "Bolee poloviny ukraintsev schitayut rossioyan bratskim narodom", Forbes (Ukraine), 16 December 2016. http://forbes.net.ua/news/1425670-bolee-poloviny-ukraincev-schitayut-rossiyan-bratskim-narodom; "Kazhdyi vtoroi ukrainets schitaet rossiyan brtskim narodom", Strana (Ukraine), 16 December 2016.

https://strana.ua/news/45634-dlya-poloviny-ukraincev-rossiyane-yavlyayutsya-bratskim-narodom-opros.html; "Polovina ukraintsev schitayut rossioyan bratskim narodom, Pravda (Ukraine), 16 December 16, https://www.pravda.com.ua/rus/news/2016/12/16/7130036/ (accessed 26 December 2016).

65 "Mozhlivsosti ta pereshkody na shlyakhu demokratichnoho perekhodu v Ukraini”, National Endowment for Democracy, conducted December 2017. Slide 19, https://www.ndi.org/sites/default/files/December\%202017\%20Polling\%20Results\%20\%28Ukrainian\%29.pdf (accessed 10 January 2018).

66 "Kazhdyi pyatyi ukrainets khochet soyuza s Rossiei in Belarusyu", Zerkalo nedeli, 22 August 2017, https://zn.ua/UKRAINE/kazhdyy-pyatyyukrainec-hochet-soyuza-s-rossiey-i-belarusyu-257914_html (accessed 16 October 2017).

${ }^{67}$ Anastasiya Rafal, "7 voprosov o tom, pochemu ukraintsy razocharovyvayutsya v evropeiskom vybore", Vesti reporter, no 28 (2015), http://reporter.vesti-ukr.com/art/y2015/n28/17502-7-voprosov-o-tom-pochemu-ukraincy-razocharovyvayutsya-v-evropejskom-vybore.html (accessed 16 June 2016).

${ }^{68}$ The fourth Annual survey of Ukrainian Municipalities, conducted February 2018, shows that while $70 \%$ in resident in western Ukrainian cities consider their ability to freely express their views as "good" or even "outstanding", in Eastern cities that number falls to less than a third. "Chetverte vseukrainske munitsipalne oputuvannia", Rating Group, 23 March 2018. Slide 23,

http://ratinggroup.ua/research/regions/chetvertyy vseukrainskiy municipalnyy opros.html (accessed 16 April 2018). The authors of another
} 
The real test for Russian soft power, however, will be whether it can shape preferences in areas of the globe that are not part of the traditional sphere of Russian cultural influence. Many are skeptical that Russian soft power, even one based on cultural diversity, can be very popular given the authoritarian nature of the regime. ${ }^{69}$

This will certainly be true for those who make the nature of the Russian regime their primary criteria in dealing with Russia, and also for those who equate the international order with American leadership. But as that order has become increasingly chaotic, some Europeans have begun to equate Russia's authoritarianism with stability and political competence, and worry more about Trump than Putin. ${ }^{70}$

A poll in 2017 showed that majorities in Slovakia (75\%), the Czech Republic (62\%) and Hungary (54\%) want closer security cooperation with Russia. ${ }^{71}$ Looking at the latest Eurobarometer poll, Anatoly Karlin suggests that we may be seeing a revival of 'conservative Russophilia' in southern and Eastern Europe. ${ }^{72}$ According to the editor of La Stampa, one of Italy's major newspapers, 'Nobody ever took this poll but I believe that if you were asking all Italians today who is the most popular foreign leader in all of Italy, Putin would win'. ${ }^{73}$ Putin's overwhelming victory to a fourth term in office as president of Russia merely burnishes this image.

To expand the reach of its soft power even further, therefore, Russia is likely to promote three themes. The first, is that it is alright for nations to be true to themselves. To succeed in the world, one does not have to move in lockstep with the western model of development. The rise of the BRICS, Russia argues, has proven that diverse approaches to development can compete very successfully with 'the Washington Consensus', and that local traditions can provide a reservoir of social resources that enhance a nation's global competitiveness. ${ }^{74}$

The second, is that it is alright for societies to challenge the ideal of a consumer oriented society. In many western and non-western societies, consumerism is blamed, not only for leading to resource, demographic, and ecological crises, but also to spiritual crises. The response has been to seek a sustainable, autochthonous source of spiritual development, upon which to build a sustainable, autochthonous form of economic development. This ties in with Russia's third

survey, "Ukraine's Generation 'Z': Values and Orientation", conducted in July-August 2017, note a "tendency to silence" and "avoidance of answers" in Southern and Eastern regions. "Thus, in the East almost $60 \%$ did not answer the question: 'Who carries the greater responsibility for starting the military conflict in Eastern Ukraine?" "Ukrainske pokolinnia 'Z': tsinnosti ta orientiry" GfK Ukraine, July-August 2017, http://www.gfk.com/fileadmin/user upload/dyna content/UA/02-News-2017/GfK-Ukr Generation ukr inet-1.pdf (accessed 16 October 2017).

${ }^{69}$ David Lane, "Soft Power, Dark Power and Academic Cooperation", Valdai Club, 10 November 2014,

http://valdaiclub.com/a/highlights/soft power dark power and academic cooperation/ (accessed 16 June 2015). For a nuanced discussion of the pros and cons of Russian soft power, see Vlad Sobell, “Does Russia have soft power and the ability to wield it?", US-Russia.org, 28 May 2013,

http://us-russia.org/1291-does-russia-have-soft-power-and-the-ability-to-wield-it.html (accessed 16 June 2013).

${ }^{70}$ Luc de Barochez, "Trump ou Poutine, lequel est le pire pour l'Europe ? Le Monde, 20 March 2018,

https://www.lopinion.fr/edition/international/trump-poutine-lequel-est-pire-l-europe-145381 (accessed 16 April 2018).

71 "Visegrad Four Poll Reveals Vulnerabilities to Russian Influence", International Republican Institute poll, 24 May 2017,

http://www.iri.org/resource/visegrad-four-poll-reveals-vulnerabilities-russian-influence (accessed 16 June 2017).

${ }_{72}$ Anatoly Karlin, "Hajnal Russophilia”, The Unz Review, 28 February 2018, http://www.unz.com/akarlin/hajnal-russophilia/ (accessed 16 March 2018).

${ }^{73}$ Frank Bruni, "Italy Has Dumped America. For Russia”. New York Times, 10 March 2018,

https://www.nytimes.com/2018/03/10/opinion/sunday/italy-has-dumped-america-for-russia.html (accessed 16 March 2018).

${ }^{74}$ For more on this, see Glenn Diesen, The Decay of Western Civilisation and Resurgence of Russia: Between Gemeinschaft and Gesellschaft

(London: Routledge, 2018). 
theme--social conservatism--which has clearly struck a chord with conservative and religious groups in both Europe and America. ${ }^{75}$

In a curious twist of politics and fate, one of the staunchest American proponents of the view Putin's conservatism makes him 'one of us', is president Nixon's former speechwriter, Patrick J. Buchanan. 'Putin', he writes, 'may be seeing the future with more clarity than Americans still caught up in a Cold War paradigm. As the decisive struggle in the second half of the 20th century was vertical, East vs. West, the 21 st century struggle may be horizontal, with conservatives and traditionalists in every country arrayed against the militant secularism of a multicultural and transnational elite'. ${ }^{76}$ More recently, he has said that, 'Where America's elites may celebrate same-sex marriage and 'reproductive rights,' more and more Europeans are identifying with the social values of Putin's Russia. Pro-Putin parties are surging in Europe. ProAmerica parties have been facing losses and defections'. ${ }^{77}$

Many liberally inclined western analysts cannot fathom why this would lead to a confluence of interests among countries as diverse as Brazil, Russia, India, China, and South Africa. A better way to think of it is this--the soft power of the BRICS is an expression not of any one set of national values, but of the common values that they feel ought to underlie a new international order.

Russia's current moral framework fits this agenda like a glove, magnifying the impact of Russian soft power. Russia now believes that it can rely on a core constituency of states to assist it in the face of intense western hostility, since its efforts benefit not only Russia, but indirectly all nations that aspire to a new, pluricultural international order.

There appears to be a growing consensus among analysts that America's post-Cold War Russia policy has failed, and that the West bears at least part of the blame for this. ${ }^{78}$ Critics say that America succumbed to the temptation to utilize its 'unipolar moment' for unilateral advantage, and failed to propose a new model for international cooperation after the end the Cold War. In retrospect, the classic arguments of political realists about what happens to nations during periods of hyper-power appear to have been vindicated. ${ }^{79}$ In repeating these mistakes, America has been anything but exceptional.

\footnotetext{
${ }^{75}$ Rod Dreher, "Russian Trads And Western Sympathizers", The American Conservative, 27 March 2017, http://www.theamericanconservative.com/dreher/russian-traditionalists-western-sympathizers/ (accessed 6 June 2018); Vincent Charles Keating and Katarzyna Kaczmarska, "Conservative Soft Power: Liberal soft power bias and the 'hidden' attraction of Russia”, Journal of International Relations and Development (2018), 1-27, http://dx.doi.org/10.1057/s41268-017-0100-6 (accessed 6 June 2018).

${ }^{76}$ Patrick J. Buchanan, "Putin's Paleoconservative Moment”. The American Conservative, 17 December 2013, http://www.theamericanconservative.com/2013/12/17/putins-paleoconservative-moment/ (accessed 16 June 2014).

${ }^{77}$ Patrick J. Buchanan, "The Rise of Illiberal Democracy", The American Conservative, 6 January 2017,

http://www.theamericanconservative.com/buchanan/the-rise-of-illiberal-democracy/ (accessed 16 January 2017).

${ }^{78}$ Thomas Graham and Matthew Rojansky, “America's Russia Policy Has Failed”, Foreign Policy, 13 October 2016, http://foreignpolicy.com/2016/10/13/americas-russia-policy-has-failed-clinton-trump-putin-ukraine-syria-how-to-fix/ (accessed 16 November 2016).; "Bundespräsident Steinmeier: Geschichte darf keine Waffe sein”, Frankfurter Allgemeine Zeitung, 23 August 2017, http://www.faz.net/aktuell/politik/frank-walter-steinmeier-in-estland-warnungen-an-russland-15163559-p2.html?printPagedArticle=trueno pageIndex_2 (accessed 26 August 2017); Evan Osnos, David Remnick, and Joshua Yaffa, “Trump, Putin, and the New Cold War”, The New Yorker, 6 March 2017, http://www.newyorker.com/magazine/2017/03/06/trump-putin-and-the-new-cold-war (accessed 6 June 2018).

${ }^{79}$ Richard Ned Lebow, The Tragic Vision of Politics (New York: Cambridge University Press, 2003); John J. Mearsheimer, "Why the Ukraine Crisis Is the West's Fault", Foreign Affairs, September/October 2014, https://www.foreignaffairs.com/articles/russia-fsu/2014-08-18/whyukraine-crisis-west-s-fault (accessed 16 June 2014).
} 
For many others, however, Russia bears the lion's share of the blame for the return of the Cold War, because it is trying to re-create the Soviet Union. ${ }^{80}$ But what Clinton and others see as merely a restoration of Soviet influence is actually something far more ambitious - the restoration of Russian power and influence, through the resurrection of traditional Russian mores and religious values. And with conservative traditionalism becoming a source of friction within so many European countries, there is the distinct possibility that a more traditional and religious Russia might someday find a way to bridge the 'values gap' with the West, not from the liberal end of the political spectrum, but from its conservative end. ${ }^{81}$

\section{Is there Life After Containment?}

At this writing, storm clouds are gathering once again over the European continent. Rather than coming together over conservative, or any other values, Russia and the West seem to be drifting further and further apart. One of the most astute Russian observers of European affairs, Sergei Karaganov, offers an intriguing analysis of why, and of what can be done about it. Karaganov serves as dean of the School of World Economics and World Politics at the National Research University-Higher School of Economics. He is also the honorary chairman of the Council on Foreign and Defense Policy, which he headed for many years. Karaganov's views are especially noteworthy because he is, simultaneously, a Russian nationalist and a committed Europeanist, who views the European model of a global humanitarian order as highly attractive, and sees the potential return of a Europe of nation-states, as 'a tragedy for Europe and a tragedy for Russia' ${ }^{82}$

Russia, which had been largely in balance with the rest of Europe for much of the twentieth century, was severely weakened by the demise of the Soviet Union, says Karaganov. During this time Europe adopted a short-sighted policy of trying to push Russia off the political, security and economic stage. ${ }^{83}$ Inevitably, however, balance was restored, and with it 'normal politics' (i.e., geopolitics) has returned. Putin began to pushback against threats to its vital national interests, and in doing so, Karaganov asserts, halted further Russian appeasement of the West, that would have most likely culminated in war. ${ }^{84}$

America meanwhile has been turning inward. This tendency, Karaganov believes, began during president Obama's second term, and is accelerating under president Trump. Such a withdrawal, Karaganov feels, is bad Russia, because it needs a functioning partner, not a paralyzed one. It is also bad for Russia relations with the EU because, Europe does not wish to bear the burden of paying for a new world order. Having concluded that neither the EU nor the United States will be a viable partner for Russia in the foreseeable future, Russia has moved on to Asia.

\footnotetext{
${ }^{80}$ Before leaving office, former U.S. Secretary of State Hillary Clinton famously accused Russia of seeking to 're-Sovietize' its neighbors: 'It's going to be called customs union, it will be called Eurasian Union and all of that', she said, 'but let's make no mistake about it. We know what the goal is and we are trying to figure out effective ways to slow down or prevent it'. Bradley Klapper, "Clinton fears efforts to 're-Sovietize' in Europe". Associated Press, 6 December 2012.

http://www.google.com/hostednews/ap/article/ALeqM5ikCSVjy7h3ksmvpbqrMYZePvSdkQ?docId=06bc71ef2209439 (accessed 16 June 2017).

${ }^{81}$ On how the liberal bias in the study of soft power underestimate Russia's potential in this arena, see Keating and Kaczmarska, "Conservative

Soft Power"; and Nicolai N. Petro, "The Surprising Allure of Russian Soft Power," American Diplomacy vol. 3, (Spring 2018),

http://www.unc.edu/depts/diplomat/item/2018/0406/ca_petro_russia.html (accessed 6 June 2018).

82 “'Bez znaniya togo kak zhivet odna kletka, nevozmozhno ponyat, kak razvivaetsya organism"', an interview with Sergei Karaganov in the $30^{\text {th }}$ anniversary of the European Instititue of the Russian Academy of Sciences, Sovremennaya Evropa, no 6 (2017), http://www.soveurope.ru/2017/06-2017/Karaganov-inter.pdf (accessed 16 August 2017).

${ }^{83}$ Sergei Karaganov, "New ideological struggle?” Russia in Global Affairs, 26 April 2016, http://eng.globalaffairs.ru/pubcol/New-ideologicalstruggle-18124 (accessed 16 May 2016).

84 'Bez znaniya".
} 
'Our Eurasian integrative project was initially aimed at utilizing the experience of European norms and institutions, to construct analogues to them around Russia, then to integrate these with Europe. Political circumstances did not permit this, and so now we will integrate with Asia. Later, step by step, perhaps, there will be a new convergence --now Eurasian--with Europe'. ${ }^{85}$

Sadly, for Karaganov, America will have almost no role in this. While some in Moscow had high hopes for an improvement of relations under Donald Trump, these hopes have been dashed by the Trump administration's prolonged inability to staff a coherent foreign policy team, and to separate his Russia policy from American domestic politics.

There is, however, one important difference between the US and the EU, says Karaganov. Whereas in the former, anti-establishment sentiment is just as Russophobic as mainstream political sentiment, in the latter it is not. Parties like the Five Star Movement in Italy, the AfD in Germany, the Republicans in France, and Fidesz in Hungary, are all eager to re-establish normal trade and relations with Russia. There simply is no constituency that supports this in the United States.

Taking Karaganov's advice to heart, suggests that the way to end the vicious circle of recriminations between Europe and Russia is to recognize that the 'values gap', which has played such a prominent role is defining difference with Russia, is largely a matter of choice. European governments choose to emphasize differences with Russia that they choose to overlook in other Western countries. Meanwhile, India and China, whose cultural differences with Russia are far greater, have been able to reach a high degree of collaboration and consensus with Russia in international affairs.

The international response to the latest poisoning incident in the United Kingdom involving Russia illustrates this divide yet again. While more than two dozen Western governments have expressed their solidarity with the UK, and expelled more than a hundred diplomats, India's former top diplomat said that such Western actions showed a 'lack of sobriety [that] only raises suspicions about Britain's version and intentions', while a leading Chinese daily described them as 'nothing more than a form of Western bullying'. ${ }^{86}$

To reach a modus vivendi with the West will therefore require a values breakthrough -- namely, the ability to envision Russia as a quintessential part of Europe. Ending Russia's estrangement from Europe would lead, as the late German president Roman Herzog once put it, to the healing of Europe's soul. ${ }^{87}$ At the end of such a process, Czech president Milos Zeman muses, tongue-incheek, 'Russia will become a member of the European Union. If you don't like that, then think of it this way: The European Union must join the Russian Federation'. ${ }^{88}$

\footnotetext{
${ }^{85} \mathrm{Ibid}$. Karaganov is unimpressed by America's pivot to Asia. For Americans, he says, turning to Asia means focusing on foreign countries and cultures that are six times zones away, whereas for Russians it means developing the larger part of their own country. "From the Pivot to the East to Greater Eurasia", International Affairs, May 2017, https://www.rusemb.org.uk/opinion/50 (accessed 16 June 2017).

${ }^{86}$ Kanwal Sibal, former foreign secretary of India, "Russia-Baiting and the International Fallout of the Murky Skripal Poisoning Case," The Wire (India), 30 March, 2018, https://thewire.in/world/russia-baiting-international-fallout-skripal-poisoning (accessed 1 May 2018); "Russian diplomat expulsions signal crude side of Western intention," Global Times (China), 27 March 2018,

http://www.globaltimes.cn/content/1095361.shtml (accessed 1 May 2018).

${ }^{87}$ Roman Herzog, "Europe Needs Russian Soul", RIA Novosti, 2 September 1997.

${ }^{88}$ Alexandra Kharchenko, “'Rossiya--chlen ES”, Vesti, 14 January 2018, https://vesti-ukr.com/politika/273177-chekhija-ukraina (accessed 16 February 2018).
} 